\title{
GROWTH CHARACTERISTICS AND REPRODUCTION OF COMBER, SERRANUS CABRILLA (ACTINOPTERYGII, PERCIFORMES, SERRANIDAE), IN THE AEGEAN SEA
}

\author{
Dilek İLHAN * , Sencer AKALIN, Zafer TOSUNOĞLU, and Okan ÖZAYDIN \\ Ege University, Faculty of Fisheries, 35100 Bornova-İzmir, Turkey
}

\begin{abstract}
İlhan D., Akalın S., Tosunoğlu Z., Özaydın O. 2010. Growth characteristics and reproduction of comber, Serranus cabrilla (Actinopterygii, Perciformes, Serranidae), in the Aegean Sea. Acta Ichthyol. Piscat. 40 (1): 55-60.
\end{abstract}

Background. Even though Serranus cabrilla has been a by-catch species in trawling operations, it is now becoming an economically important fish species on the Turkish Coast of Aegean Sea, because of its low market price. For an efficient fisheries management of the stocks it is important to know important biological parameters of the commercially exploited species. Therefore the aim of this study was to obtain necessary growth- and reproductive characteristics of comber representing the local population of this fish in the study area.

Materials and Methods. Biological aspects of comber were examined based on a total of 1452 specimens collected from the Aegean Sea, during the period January 2005-December 2005. Age of fish was determined by otolith reading. Length-weight relation and the von Bertalanffy equation were used to evaluate the fish growth. Results. Annuli on otoliths indicated the presence of 6 age classes. The computed growth parameters were: $L_{\infty}=23.88 \mathrm{~cm} ; k=0.298$ year $^{-1}$ and $t_{\mathrm{o}}=-1.577$ year. The length-weight relations were calculated as: $W=0.0111 \cdot L^{2.998}$ for sex combined. The growth performance index $\left(\Phi^{\prime}\right)$ was 2.230 . The fish mature sexually for the first time at a total length of $13.20 \mathrm{~cm}\left(L_{50}\right)$. The spawning season of comber was from March to May, with a peak in April.

Conclusion. The comber grows rapidly attaining almost $75 \%$ of its linear growth during the first two years of life and then the growth slows down. The growth coefficient, $(k)$, indicates slow attainment of maximum size because of significantly correlated to temperature of sea water, leading to a considerable variability in the life span between areas.

Keywords: Age, growth, reproduction, comber, Serranus cabrilla, Aegean Sea

\section{INTRODUCTION}

The comber, Serranus cabrilla (Linnaeus, 1758), is a moderately exploited commercial serranid species occurring in the Eastern Atlantic and the Mediterranean to a depth of $500 \mathrm{~m}$, on rocks, Posidonia beds, sandy and muddy bottoms (Whitehead et al. 1986). Aegean Sea is an important region for the Turkish fishing industry, accounting for $44386 \mathrm{t}$ total catch. S. cabrilla is reported to have contributed about $0.18 \%$ (in weight) in total catch, which included 64 fish species in the Aegean Sea (Anonymous 2007).

In spite of its wide distribution, this species is especially a by catch species for trawls and trammel nets and has a minor commercial value, so that knowledge on the biology of this species is incomplete and scarce when compared by other demersal fish species in the area.

Bouain 1981 and Benmouna et al. 1984, who studied comber, focused on the physiology and reproductive biology of the species, ignoring growth and mortality, crucial for stock assessment. Papaconstantinou et al. (1994) reported data on the growth parameters and the length at first maturation for comber in the North Aegean Sea (Greece), while Politou and Papaconstantinou (1995), presented growth parameters and age composition of comber in the Northern Greece. Feeding habits of this species were determined in the Canary Islands by Tuset et al. (1996). Stergiou (1997) and García-Díaz et al. (1997) examined the spawning seasonality and the sex and reproductive aspects in Serranus cabrilla in the English Channel and the Canary Island, respectively. The length-weight relations for comber were presented by Gonçalves et al. (1997) and Stergiou and Motopoulos (2001) in south-west coast of Portugal and Greek waters, respectively. Tserpes and Tsimenides (2001) reported data on the age, growth, and mortality of comber from the Cretan shelf. Shape indices to identify regional differences in otolith morphology of comber otoliths were examined by Tuset et al. (2003) from the Atlantic and Mediterranean. From Turkish Seas, Türker-Cakır and Torcu-Koc (2002) examined its feeding habits and also

\footnotetext{
* Correspondence: Dr. Dilek İLHAN, Ege Üniversitesi, Su Ürünleri Fakültesi, 35100 Bornova-İzmir, Türkiye, phone: + 902323884000 / 5341, e-mail: d.uckun.ilhan@gmail.com.
} 
Torcu-Koc et al. (2004) investigated its age, growth and mortality in the Edremit Bay. The present work is mainly intended to provide information on age, growth and reproductive biology of the comber in the Aegean Sea.

\section{MATERIALS AND METHODS}

A total of 1452 Serranus cabrilla specimens were collected during demersal trawl trials carried out on board $R / V$ EGESÜF (27 m LOA, $\sim 372 \mathrm{~kW}$ main engine) in the Izmir Bay (Aegean Sea) between January and December 2005. The samples obtained were measured to the nearest 0.1 $\mathrm{cm}$ total length (TL) and weighed to the nearest $0.1 \mathrm{~g}$.

Age was determined by otolith reading. The otoliths were removed from all specimens and stored dry in labelled envelopes. All otoliths were cleaned in $4 \%$ $\mathrm{NaOH}$ and transferred in $70 \%$ alcohol. Annuli of the whole otoliths from each individual were determined under reflected light using a binocular microscope at a magnification of $10 \times$ against a black background (Chilton and Beamish 1982). To minimize reading errors, the number of opaque rings outside the nucleus was evaluated by two readers (Fig. 1). For all otoliths, the date of capture was recorded and known to the readers before reading, together with the date of hatching. The difference between the date of hatching and capture helped readers to calculate the annual fraction elapsed since the hatching date, which was added to the number of complete hyaline zones read in the otoliths (Gordoa and Moli 1997). Formations of otolith opaque zone are thought to relate to spawning activities, water temperature, or food supply (Beckman and Wilson 1995). In the presently reported results, formation of the opaque zone in comber otolith was confirmed from March to May with the peak in April, and these months corresponded to the spawning season which is also confirmed in the Edremit Bay (Aegean Sea) during March and May (Torcu-Koc 2004) and in the Mediterranean during April and July (Whitehead et al. 1986). If the readings did not coincide, the otolith was rejected.

The age rings in the first years of life are more uniform than those representing subsequent years. The pace of the fish growth is inconsistent with the otolith growth, so the rings can be closer to the each other, making their identification more difficult.

When we are encountered an otolith with overlapping rings on the edge we rejected the otolith from our estimations. As all Serranus species are simultaneous hermaphrodites (García-Díaz et al. 1997), age analysis was carried out independently of sex.

The commonly used length-weight relation $W=\mathrm{a} \cdot L^{b}$ was applied (Ricker 1975), where $W$ is the weight (g), $L$ the total length (cm), and $a$ and $b$ are constants.

Mean length at age data were used to estimate the growth parameters of the von Bertalanffy Growth Function (VBGF) (Ricker 1975): $L_{t}=L_{\infty}\left(1-\mathrm{e}^{-k\left(t-t_{0}\right)}\right)$ where $L_{t}$ is the FL of fish at time $t, L_{\infty}$ is the ultimate length an average fish could achieve, $k$ is the growth constant which determines how fast the fish approaches $L_{\infty}$ and $t_{0}$ is the hypothetical age at $L_{t}=0$.
The growth performance index (Gayanilo and Pauly 1997) was calculated to provide a basis for the comparison of growth characteristics in terms of length: $\Phi^{\prime}=\log (k)+$ $2 \log \left(L_{\infty}\right)$ where $k$ and $L_{\infty}$ are the VBGE parameters. The hypothesis of isometric growth (Ricker 1975) was tested by Student's $t$-test.

Stage of gonad maturity based on the modified empirical scale of Holden and Raitt (1974). This scale has four stages: 1 = immature, 2 = maturing, 3 = ovipositing, and 4 = postoviposition, and seems more discriminate and less subject to interpretative error than other scales.

The gonadosomatic index was determined as follows: GSI $=\left(\right.$ gonad weight $\times$ body weight $\left.{ }^{-1}\right) \times 100$.

The average GSI values were calculated monthly from January to December for adult individuals.

For the estimation of the mean lengths at 50\% maturity, a logistic function was fitted to the proportion of the mature individuals by size class using a nonlinear regression The function used was after King (1995): $\mathrm{P}=1(1+$ $\left.\exp \left[-r\left(L-L_{m}\right)\right]\right)$, where $\mathrm{P}$ is the proportion mature in each size class, $r$ is the slope of the curve and $L_{m}$ is the mean length at sexual maturity $(50 \%)$.

\section{RESULTS}

Age and growth. Our field surveys covered a period of 12 consecutive months (January-December 2005) during which we collected and measured the total lengths of 1453 Serranus cabrilla specimens, ranging from 7.40 to $22.50 \mathrm{~cm}$ (Fig. 2). The bulk of the specimens presented distinctive peaks at $11.00 \mathrm{~cm}(14 \%)$ and $17.00 \mathrm{~cm}(12 \%)$, respectively.

A total of 551 specimens was aged. The results of age are presented in Table 1. Age estimates ranged between 0 and 6 years and the II and III age groups included the highest number in all samples. The growth is rapid in the first 2 years of life, also it can be observed from the ring structure of the otoliths.

The von Bertalanffy (1960) growth parameters were calculated as: $L_{\infty}=23.88 \mathrm{~cm}(\mathrm{SE}= \pm 0.752), k=0.298$ year $^{-1}(\mathrm{SE}= \pm 0.030)$ and $t_{0}=-1.577(\mathrm{SE}= \pm 0.147)$ year for all specimens $\left(R^{2}=0.917\right)$.

Considering the $L_{\infty}$ and to $\mathrm{k}$ values, growth performance index value $\left(\Phi^{\prime}\right)$ was computed as; 2.230 for combined sex.

Length-weight relation. The length-weight relations were calculated as: $W=0.0111 \cdot L^{2.998}$ for all individuals (Fig. 3). According to Student's $t$-test, we observed isometric growth for this species in the research area $(b=2.998 ; \pm \mathrm{SE}(b)=0.0103 ; P>0.05)$.

Size at first maturity and gonadosomatic index. Data displayed in Fig. 4 present the percentage of most matured individuals (maturity stages II-IV) of comber as a function of length class. They were determined by macroscopical analysis. According to the estimated data, length at first sexual maturity was found as $L_{50}=13.20 \mathrm{~cm}$ for all specimens.

The mean monthly GSI values are shown in Fig. 5. The GSI values started to increase in March, peaked in April, and declined June. These data suggest that the reproduction season is between March and May. 


\section{DISCUSSION}

The maximum observed life span for comber, S. cabrilla, in the Aegean Sea was 6 years for all individuals. Tserpes and Tsimenides (2001) obtained the maximum age to be 5 for all fish in the Cretan Shelf. TorcuKoc et al. (2004), examined 595 comber specimens from Edremit Bay, determined the maximum age to be 4 for all individuals. Edremit Bay was closed to the trawling operations in 1995 (2 years earlier than the sampling of Torcu-Koc et al. 2004), so the overfishing by trawls before the date may affected the comber population negatively as on other demersal fish stocks in the area. Politou and Papaconstantinou (1995) indicated a longer life-span and interpreted ages up to 8 for the species. But they have studied a total of 665 specimens which includes only 9 fishes bigger that 6 years old ( 7 of 7 and 2 of 8 years old).

So we can say that the longevity of the specimens is depend on the ecological factors (like food availability, predation, competition etc.) and the fishing activities on

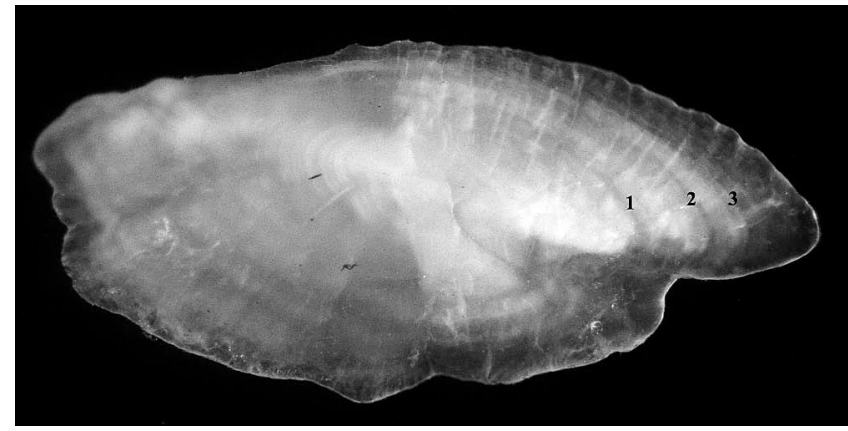

Fig. 1. Otolith of a 3+ year old S. cabrilla caught in November 2005 in the Izmir Bay; Presumed annuli are marked by respective numbers

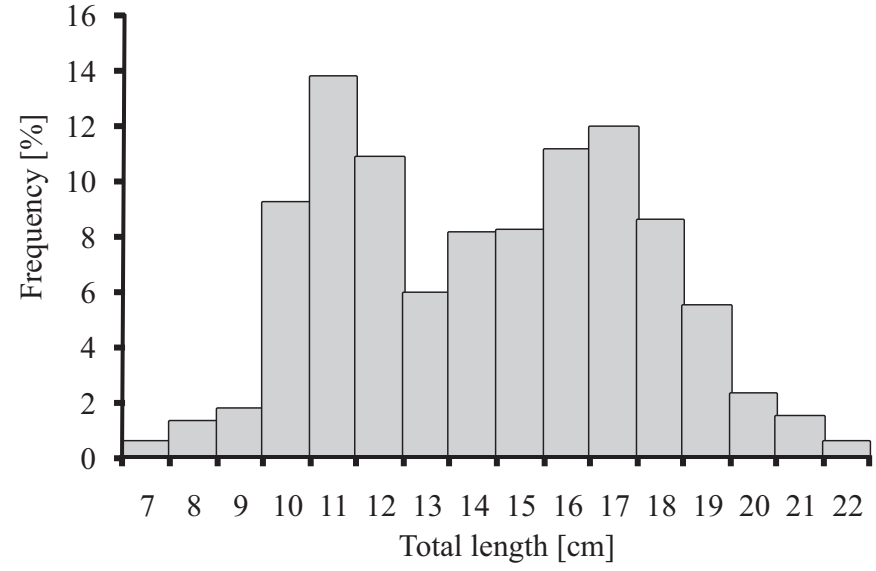

Fig. 2. Otolith of a 3+ year old S. cabrilla caught in November 2005 in the Izmir Bay; Presumed annuli are marked by respective numbers

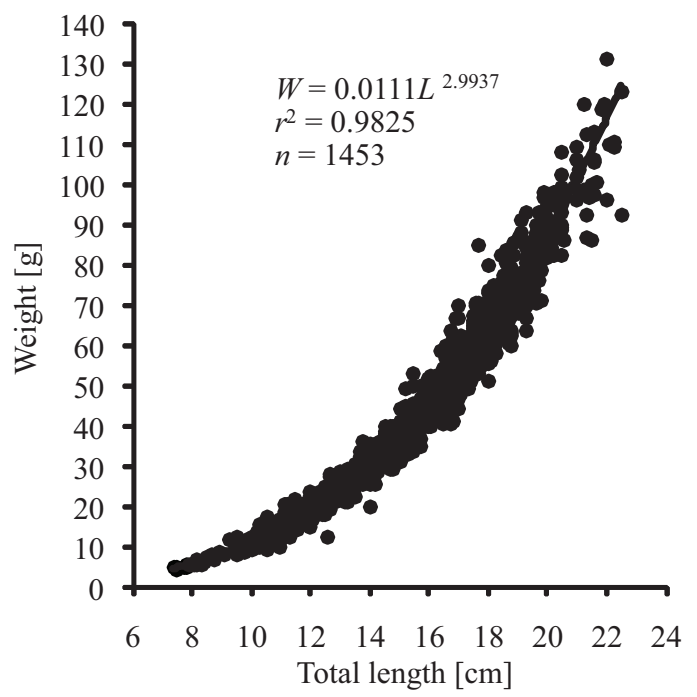

Fig. 3. Length-weight relation of Serranus cabrilla from the Izmir Bay 
Table 1

Total length at age values $(\mathrm{cm})$ of the Serranus cabrilla from the Izmir Bay

\begin{tabular}{lccccc}
\hline Age Group & $n$ & Mean TL & Standard error (se) & TL range & $\begin{array}{c}\text { Mean size } \\
\text { increment }\end{array}$ \\
\hline 0 & 84 & 10.09 & 0.168 & $7.40-12.90$ & 2.70 \\
I & 161 & 12.79 & 0.122 & $10.10-15.80$ & 3.04 \\
II & 113 & 15.84 & 0.100 & $13.00-16.00$ & 1.78 \\
III & 114 & 17.61 & 0.037 & $16.00-19.10$ & 1.59 \\
IV & 44 & 19.20 & 0.086 & $18.00-20.50$ & 1.40 \\
V & 24 & 20.61 & 0.165 & $19.00-21.70$ & 0.81 \\
VI & 11 & 21.42 & 0.272 & $20.00-22.50$ & \\
\hline
\end{tabular}

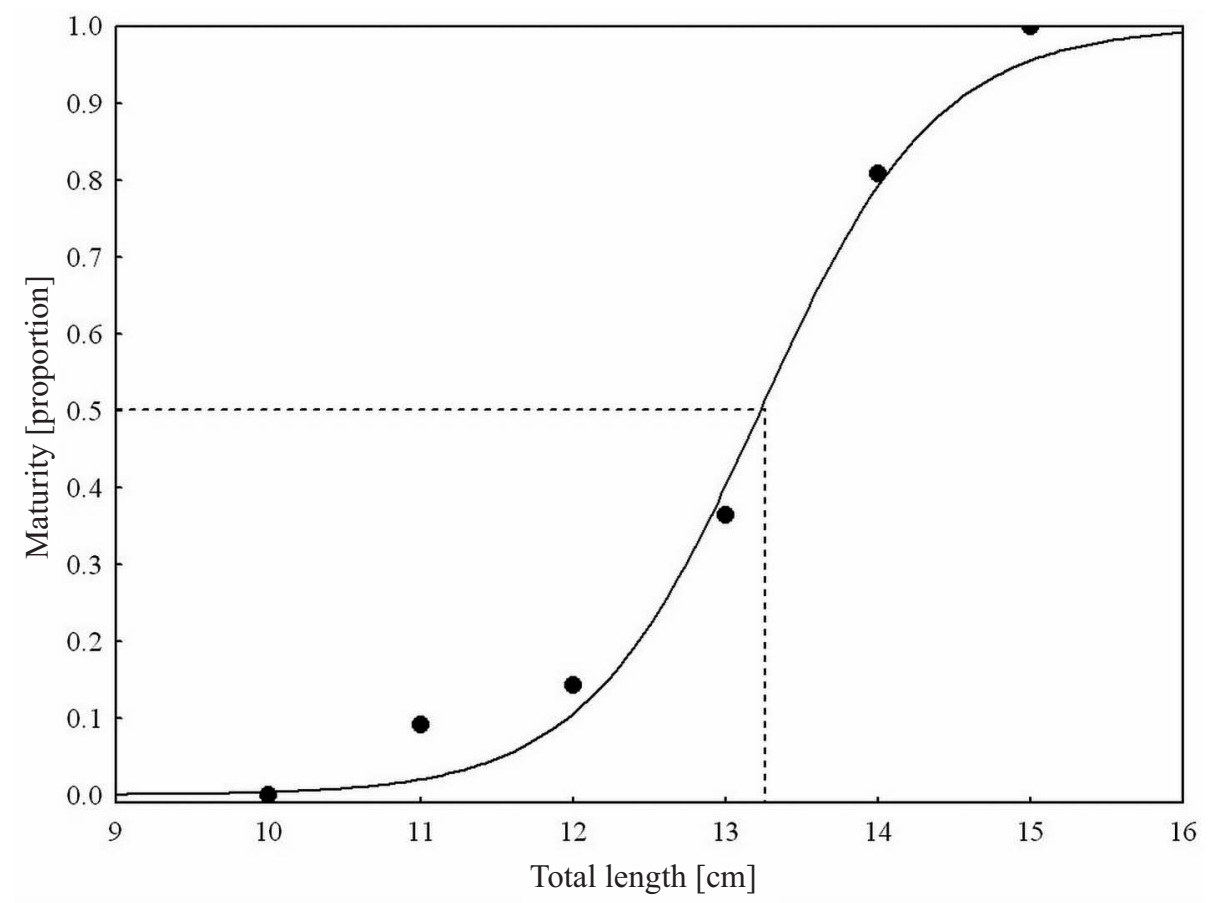

Fig. 4. The maturity curve of S. cabrilla as a function of size

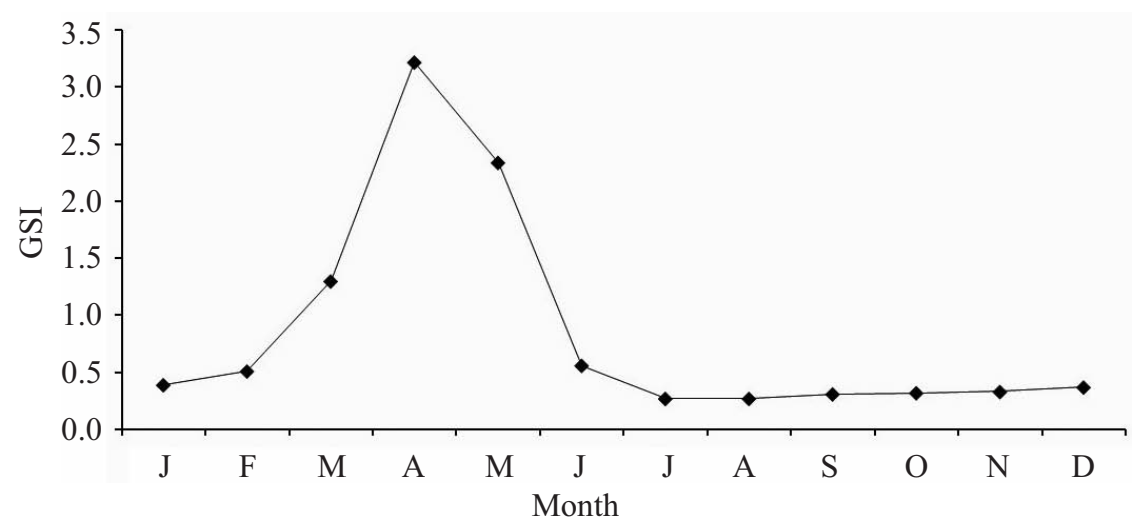

Fig. 5. Monthly variation of the mean values of gonadosomatic index (GSI) of Serranus cabrilla, January 2005-December 2005 from the Izmir Bay

the area. The absence of older ages group can be 3 years of its lifespan, attaining almost $75 \%$ its body explained their rarity in the population and our randomly length at the end of age $2(15.84 \mathrm{~cm}$ TL). The species in samplings. In addition, this may be caused by the differ- the present study was more or less similar in length at all ence in the readability of opaque zones among otoliths ages than from The Cretan shelf, while it was bigger than and/or counting skills of readers (Gunn et al. 2008). Greek Sea and Edremit Bay. The differences can be caused

Comparison of mean length values per age groups is by the different abiotic or biotic factors such as availabiligiven in Table 2. The comber grows rapidly in the first ty of food items and competition for them or the fishing 
Table 2

Average length values (cm) vs age groups of the Serranus cabrilla population in various seas

\begin{tabular}{lcccccccccc}
\hline \multirow{2}{*}{ Source } & \multicolumn{10}{c}{ Age group } \\
\cline { 2 - 11 } & 0 & I & II & III & IV & V & VI & VII & VIII & $\Phi^{\prime}$ \\
\hline Politou and Papaconstantinou (1995) & - & 11.27 & 13.36 & 15.89 & 18.31 & 19.67 & 21.26 & 21.76 & 21.70 & 2.231 \\
Tserpes and Tsimenidis (2001) & 8.75 & 11.85 & 15.10 & 17.91 & 19.30 & 19.91 & - & - & - & 2.280 \\
Torcu et al. (2004) & - & 12.28 & 14.60 & 16.37 & 18.55 & - & - & - & - & 2.432 \\
Presently reported study & 10.09 & 12.79 & 15.84 & 17.61 & 19.20 & 20.61 & 21.42 & - & - & 2.230 \\
\hline
\end{tabular}

activities in the areas. Beside it may be depended on the length distribution of the aged samples. When we compare our length distribution with the results of Torcu-Koc et al. (2004) (between $13.00 \mathrm{~cm}$ and $17.00 \mathrm{~cm} ; 80 \%$ ), most of our samples $(93 \%)$ between $10.00 \mathrm{~cm}$ and $19.00 \mathrm{~cm}$. So the difference of the length can be also reflected of the different growth rates in the age groups.

Theoretical maximal length $(23.90 \mathrm{~cm})$ seems to be realistic, since the largest specimens sampled during the surveys was $22.50 \mathrm{~cm}$. Concerning the Greek waters, this parameter was also in accordance with the findings of Politou and Papaconstantinou (1995) and Tserpes and Tsimenides (2001), who reported the asymptotic length for comber as $23.80 \mathrm{~cm}$ and $22.40 \mathrm{~cm}$, respectively. However, this value is substantially more than Torcu-Koc et al. (2004) values $(33.50 \mathrm{~cm})$. Differences noted in length may be attributed to variation in temperature and, possibly, differences in feeding habits.

The growth coefficient, $k=0.298$ year $^{-1}$, indicates slow attainment of maximum size. Politou and Papaconstantinou (1995) recorded similar result $\left(0.3\right.$ year $\left.^{-1}\right)$ with our value. The estimated $k$-value 0.24 year $^{-1}$ for comber from Edremit Bay (Torcu-Koc et al. 2004) appears to be low, because of the high asymptotic calculated length of their data. However, the growth parameters are significantly correlated to temperature of sea water, leading to a considerable variability in the life span between areas (Taylor 1958).

Isometric growth between size and weight was observed as $b=2.998$ all individuals. Similar results were reported by Petrakis and Stergiou (1995) $(b=2.92)$ for Greek waters, by Karakulak et al. (2006) $(b=2.997)$ for Northern Aegean Sea, Özaydin et al. (2007) $(b=2.992)$ for the Izmir Bay. However, different values were presented by Politou and Papaconstantinou (1995) $(b=2.725)$ for the Thermaikos Gulf, by Torcu-Koc et al. (2004) $(b=2.67)$ for Edremit Bay and by Gonçalves et al. (1997) $(b=2.661)$ for South-west coast of Portugal. The differences are probably associated with the various types of sampling and the different size structure as well as the number of observed individuals of the studies. Besides, this may be because of interannual changes in the nutritional condition of the organisms (Zorica et al. 2006).

The growth performance index $\left(\Phi^{\prime}\right)$ is considered a useful tool for comparing the growth curves of different populations of the same species or different species belonging to the same family (Sparre et al. 1987, Wootton 1990). When we compare the $\Phi^{\prime}$ of this study with other research, no statistical differences are discernible $(t$-test, $P<0.05$ ) (Table 2 ).
The first maturity of comber was estimated as $13.20 \mathrm{~cm}$ TL, in the study area. García-Díaz et al. (1997) pointed out that this species attains sexual maturity in 15.40 and 15.20 $\mathrm{cm}$ SL for macroscopic and histological methods, respectively, in the Canary Islands. For Edremit Bay, this value was reported as $15.00 \mathrm{~cm}$ SL by Torcu-Koc et al. (2004).

Macroscopic examination of the ovotestes of Serranus cabrilla revealed a single sexual type: hermaphroditic. This has already been reported by numerous authors (e.g., D’Ancona 1949, Bauchot 1987, García-Díaz et al. 1997).

The spawning season apparently varies from area to area, because of differences in hydrographic and climatic conditions. Based on the mean monthly GSI values, we can affirm that the spawning season for comber in the study area occurs between March and May, with the peak in April. García-Díaz et al. (1997) stated that the spawning season of comber was from February to July, with the highest percentage recorded in May, in the Canary Islands. Torcu-Koc et al. (2004) also determined that its reproduction occurred between March and May, peaking in April for Edremit Bay. In the Mediterranean and English Channel, combers spawns primarily in April-July and July-August, respectively (Whitehead et al. 1986).

\section{REFERENCES}

Anonymous 2007. Devlet İstatistik Enstitüsü Yayınları. [Fisheries statistics.] State Institute of Statistics Prime Ministry, Republic of Turkey, Ankara. [In Turkish.]

Bauchot M.-L. 1987. Serranidae. Pp. 1301-1319. In: Fischer W., Schneider M., Bauchot M.-L. (eds.) Fiches FAO d'identification des espéces pour les besoins de la péche. (Révision 1). Méditerranée et mer Noire. Zones de péche 37. Vol. 2. FAO/EEC, Rome.

Beckman D.W., Wilson C.A. 1995. Seasonal timing of opaque zone formation in fish otoliths. Pp. 27-43. In: Secor D.H., Dean J.M., Campana S.E. (eds.) Recent developments in fish otolith research. University South Carolina Press, Columbia, SC, USA.

Benmouna H., Trabert I., Vandewalle P., Chardon M. 1984. Comparaison morphologique du neurocrane et du splanchnocrane de Serranus scriba (Linne, 1758) et de Serranus cabrilla (Linne, 1958). Cybium 8: 71-93.

Bouain A. 1981. Les serrans (Teleostei, Serranidae) des cotes sud de la Tunisie: taille de premiere maturite, periode de reproduction. Cybium 5: 65-75.

Chilton D.E., Beamish R.J. 1982. Age determination methods for fishes studied by the groundfish program at the Pacific 
Biological Station. Canadian Special Publication of Fisheries and Aquatic Science 60.

D'Ancona U. 1949. Osservazioni sull' organizzazione della gonade ermafrodita di alcuni Serranidi. Nova Thalassia 1: 1-15.

García-Díaz M.M., Tuset V.M., González J.A., Socorro J. 1997. Sex and reproductive aspects in Serranus cabrilla (Osteichthyes: Serranidae): macroscopic and histological approaches. Marine Biology 127 (3): 379-386. DOI: 10.1007/s002270050024.

Gayanilo F.C., Pauly D. (eds.) 1997. FISAT, FAO-ICLARM Stock assessment tools reference manual. Computerized Information, Series Fisheries. FAO, Rome.

Gonçalves J.M.S., Bentes L., Lino P.G., Riberio J., Canário A.V.M., Erzini K. 1997. Weight-length relationships for selected fish species of the small-scale demersal fisheries of the south-west coast of Portugal. Fisheries Research 30 (3): 253-256. DOI: 10.1016/S0165-7836(96)00569-3.

Gordoa A., Moli B. 1997. Age and growth of the sparids Diplodus vulgaris, D. sargus and D. annularis in adult populations and the differences in their juvenile growth patterns in the north-western Mediterranean Sea. Fisheries Research 33 (1-3): 123-129. DOI: 10.1016/S0165-7836(97)00074-X.

Gunn J.S., Clear N.P., Carter T.I., Rees A.J., Stanley C.A., Farley J.H., Kalish J.M. 2008. Age and growth in southern bluefin tuna, Thunnus maccoyii (Castelnau): Direct estimation from otoliths, scales and vertebrae. Fisheries Research 92 (2-3): 207-220. DOI: 10.1016/j.fishres.2008.01.018.

Holden M.J., Raitt D.F.S. 1974. Manual of fisheries science. Part. 2 - Methods of resource investigation and their application. FAO Fisheries Technical Papers 115.

Karakulak F.S., Erk H., Bilgin B. 2006. Length-weight relationships for 47 coastal fish species from the northern Aegean Sea, Turkey. Journal of Applied Ichthyology 22 (4): 274-278. DOI: 10.1111/j.1439-0426.2006.00736.x.

King M.G. 1995. Fisheries biology, assessment and management. Fishing News Blackwell Scientific Books. Oxford, England.

Özaydın O., Uçkun D., Akalın S., Leblebici S., Tosunoğlu Z. 2007. Length-weight relationships of fishes captured from Izmir Bay, central Aegean Sea. Journal of Applied Ichthyology 23 (6): 695-696. DOI: 10.1111/j.1439-0426.2007.00853.x.

Papaconstantinou C., Politou C.Y., Caragitsou E., Stergiou K.I., Mytilineou E., Vassilopoulou V., Fourtouni A., Karkani, M., Kavadas S., Petrakis G., Siapatis A., Chatzinikolaou P., Giagnisi M. 1994. Investigations on the abundance and distribution of demersal stocks of primary importance in the Thermaikos Gulf and the Thracian Sea (Hellas). National Centre for Marine Research, Athens, Hellas, Technical Report, North Aegean Sea Series 4/1994.

Petrakis G., Stergiou K.I. 1995. Weight-length relationships for 33 fish species in Greek waters. Fisheries Research 21 (3-4): 465-469. DOI: 10.1016/0165-7836(94)00294-7.

Politou C.-Y., Papaconstantinou C. 1995. Age and growth of comber, Serranus cabrilla (L., 1785) in the Thracian Sea and the Thermaikos Gulf (Northern Greece). Rapport. Commission Internationale Mer Méditerranée 34.

Ricker W.E. 1975. Computation and interpretation of biological statistics of fish populations. Bulletin of the Fisheries Research Board of Canada 191: 1-382.

Sparre P., Ursin E., Venema S.C. 1987. Introduction to tropical fish stock assessment. Part 1. Manual FAO Fisheries Technical Paper 306.

Stergiou K.I. 1997. The hellenic seas: Physics, chemistry, biology and fisheries. Pp. 415-538. In: Oceanography and marine biology: An annual review. UCL Press.

Stergiou K.I., Motopoulos D.K. 2001. A review of length-weight relationships of fishes from Greek marine waters. Naga, the ICLARM Quarterly 24 (1-2): 23-39.

Taylor C.C. 1958. Cod growth and temperature. Journal du Conseil - Conseil International pour l'Exploration de la Mer 23: 366-370.

Torcu-Koc H., Türker-Cakır D., Dulčić J. 2004. Age, growth and mortality of the comber, Serranus cabrilla (Serranidae) in the Edremit Bay (NW Aegean Sea, Turkey). Cybium, 28 (1): $19-25$.

Tserpes G., Tsimenides N. 2001. Age, growth and mortality of Serranus cabrilla (Linnaeus, 1758) on the Cretan shelf. Fisheries Research 51 (1): 27-34. DOI: 10.1016/S0165-7836(00)00237-X.

Tuset V.M., González J.A., García-Díaz M.M., Santana J.I. 1996. Feeding habits of Serranus cabrilla (Serranidae) in the Canary Islands. Cybium 20: 161-167.

Tuset V.M., Lozano I.J., González J.A., Pertusa J.F., García-Díaz M.M. 2003. Shape indices to identify regional differences in otolith morphology of comber Serranus cabrilla (L., 1758). Journal of Applied Ichthyology 19 (2): 88-93. DOI: 10.1046/j.1439-0426.2003.00344.x.

Türker-Cakır D., Torcu-Koc H. 2002. Feeding habits of Serranus cabrilla (Serranidae) in Edremit bay (Aegean Sea). Pakistan Journal of Biological Sciences 5 (10): 1131-1134.

von Bertalanffy L. 1960. Principles and theory of growth. Pp 137-259. In: Nowinski W.W. (ed.) Fundamental aspects of normal and malignant growth. Elsevier, Amsterdam.

Whitehead P.J.P., Bauchot M.-L., Hureau J.-C., Nielsen J., Tortonese E. (eds.) 1986. Fishes of the north-eastern Atlantic and the Mediterranean. Vol. 2. UNESCO, Paris.

Wootton R.J. 1990. Ecology of teleost fishes. Chapman and Hall, England.

Zorica B., Sinovčić G., Pallaoro A., Čikeš Keč V. 2006. Reproductive biology and length-weight relationship of painted comber, Serranus scriba (Linnaeus, 1758), in the Trogir Bay area (middle-eastern Adriatic). Journal of Applied Ichthyology 22 (4): 260-263. DOI: 10.1111/j.1439-0426.2006.00632.x.

Received: 31 August 2009

Accepted: 1 February 2009

Published electronically: 25 June 2010 